Boston University School of Law Scholarly Commons at Boston University School of Law

Faculty Scholarship

2018

\title{
Greeted with a Shrug: The Impact of the Community Design System on United States Law
}

Stacey Dogan

Boston Univeristy School of Law

Follow this and additional works at: https://scholarship.law.bu.edu/faculty_scholarship

Part of the Intellectual Property Law Commons

\section{Recommended Citation}

Stacey Dogan, Greeted with a Shrug: The Impact of the Community Design System on United States Law, The EU Design Approach: A Global Appraisal (2018).

Available at: https://scholarship.law.bu.edu/faculty_scholarship/410 


\title{
Chapter 9. Greeted with a Shrug: The Impact of the Community Design
}

\author{
System on United States Law
}

\section{Stacey Dogan*}

I. Introduction

In an era of increased harmonization of intellectual property laws worldwide, the United States' treatment of product design looks like an anomaly. Since the European Community Design System went into effect in 2002, advocates in the US have urged Congress to follow suit and adopt sui generis design protection, particularly for fashion. ${ }^{1}$ The US Congress, however, has resisted the call and left design protection to the existing standards of trademark, copyright and design patent law. ${ }^{2}$

The legislature's recalcitrance on design is not entirely a byproduct of current Congressional dysfunction. ${ }^{3}$ Other, more productive Congresses have considered and rejected design protection in the past, most notably in connection with the 1976 overhaul of the Copyright Act. ${ }^{4}$ Then as now, the rejection of design rights arose from a confluence of factors, some substantive and some more pragmatic. The substantive concerns include the utilitarian tradition of US intellectual property law, with its ostensible preference for competition over exclusivity; this model eschews new forms of exclusive rights, except when necessary to incentivize creators and avoid market

\footnotetext{
* Thanks to Stuti Venkat, Sriya Coomer, and Andrew Norkiewicz for excellent research assistance.

${ }^{1}$ E.g., T. Mahmood, Note: Design Law in the United States as Compared to the European Community Design System: What Do We Need to Fix? [2014] 24 Fordham Intell. Prop. Media and Ent. L.J. 555; C. S. Hemphill and J. Suk, The Law, Culture, and Economics of Fashion [2009] 61 Stan. L. Rev. 1147; See generally Design Piracy Prohibition Act, H.R. 2196, 111th Cong. [2009]; Design Piracy Prohibition Act, S. 1957, 110th Cong. [2007]; Design Piracy Prohibition Act, H.R. 5055, 109th Cong. [2006].

2 See generally M. A. Lemley and M. P. McKenna, Scope [2016] 57 Wm. and Mary L. Rev. 2197; M. P. McKenna and C.J. Sprigman, What's In, and What's Out: How IP's Boundary Rules Shape Innovation [2017] 30 Harv. J.L. and Tech. 491.

${ }^{3}$ M. Ellement, The Supreme Court Meets a Gridlocked Congress [2016] 84 Geo. Wash. L. Rev. Arguendo 116, 166 (noting that Congress is currently "at a standstill-increasingly unable to agree on, or even debate, new legislation”); J. Steinhauer and D. M. Herszenhorn, 'Congress Recesses, Leaving More Stalemates Than Accomplishments' (N.Y. Times 14 July 2016)

$<$ https://www.nytimes.com/2016/07/15/us/politics/congress-recesses-leaving-more-stalemates-thanaccomplishments.html> accessed 24 November 2017.

${ }^{4}$ See An Act for the General Revision of the Copyright Law, Title 17 of the United States Code, and for Other Purposes S. 22, 94th Cong. [1975]; S. Rep. No. 94-473, 94th Cong. [1975]; cf. H.R. Rep. No. 941476 [1976]; see generally J.H. Reichman, Design Protection in Domestic and Foreign Copyright Law: From the Berne Revision of 1948 to the Copyright Act of 1976 [1983] Duke L.J. 1143, 1188-90; R. S. Brown, Jr., Design Protection: An Overview [1987] 34 UCLA L. Rev. 1341, 1396 ("Beginning in 1957, a [design] bill has been introduced in probably every Congress, in a form closely resembling the current model.").
} 
failure. ${ }^{5}$ This commitment to core principles, of course, tells only part of the story, since Congress adheres to it selectively; some new rights have emerged despite little evidence that they will meaningfully affect incentives or serve other utilitarian goals. ${ }^{6}$ Nonetheless, the utilitarian foundations of US intellectual property law help to situate the country's approach to design protection, in comparison to jurisdictions with different philosophical traditions. In particular, because US law aims to promote progress rather than to reward individual creators, lawmakers may resist arguments that prevail in jurisdictions with a stronger emphasis on rewards or moral rights. ${ }^{7}$

While a commitment to utilitarianism explains some of the US resistance to sui generis design rights, other factors have played an important role. Definitional problems that have long plagued design litigation do not disappear when protection shifts from existing IP rights into some new legal form. Nor does sui generis protection solve enforcement, overlap, or patent-deference concerns. Political economy considerations that have supported expansions of other IP rights play out differently in the product design context. Perhaps most importantly, US design patent law has evolved into a viable form of protection for many types of design. ${ }^{8}$ Together, these factors have prevented the US from following Europe's lead in adopting a regime like the Community Design System.

The absence of sui generis design protection does not, however, mean an absence of legal protection for design. Despite its practical and theoretical hurdles, there is broad intuitive appeal to the notion that creative designers deserve some form of protection against copying. At times, this has led courts to find outlets for design protection under copyright and trademark/unfair competition law. Throughout the twentieth and early twenty-first century, these areas of law expanded and contracted in response to perceived gaps or gluts in protection for design. ${ }^{9}$ Design patent law, moreover, which

\footnotetext{
${ }^{5}$ See Graham v. John Deere Co. [1966] 383 U.S. 1, 5-11 ("The inherent problem [in devising a patent system] was to develop some means of weeding out those inventions which would not be disclosed or devised but for the inducement of a patent."); see generally W. M. Landes and R. A. Posner, The Economic Structure of Intellectual Property Law (Belknap Press 2003) ("Skeptics of government should hesitate to extend a presumption of efficiency to a process by which government grants rights to exclude competition with the holders of the rights."); P. S. Menell and S. Scotchmer, 'Intellectual Property' in: A. Mitchell Polinksy and S. Shavell (eds.) Handbook of Law and Economics (Elsevier 2007); see also Letter from Thomas Jefferson to Isaac McPherson [1813] (on file with Library of Congress).

${ }^{6}$ See, e.g., Federal Trademark Dilution Act of 1995, Pub. L. No. 104-98, 109 Stat. 985 [1996] (codified as amended at 15 U.S.C. para 1125(c)); cf. R. Tushnet, 'Gone in Sixty Milliseconds: Trademark Law and Cognitive Science' [2008] 86 Tex. L. Rev. 507, 510 ("Dilution is, ultimately, an underevidenced concept and one that invites socially wasteful litigation."); see also Sony Bono Copyright Term Extension Act of 1998, Pub. L. No. 105-298, 112 Stat. 2827 [1998]; cf. Eldred v. Ashcroft [2004] 537 U.S. 186, 222 (upholding copyright term extension despite scant evidence of any effect on incentives: "The wisdom of Congress' action ... is not within our province to second-guess").

7 See generally R. J. DaSilva, 'Droit Moral and the Amoral Copyright: A Comparison of Artists' Rights in France and the United States' [1980] 28 Bull. Copyright Soc'y 1; L. Zemer, 'Moral Rights: Limited Edition' [2011] 91 B.U. L. Rev. 1519.

8 See, e.g., Apple Inc. v. Samsung Elecs. Co. Ltd. [2015] 786 F.3d 983, 1001-02; see also Sarah Burstein, 'Costly Designs' [2016] 77 Ohio St. L.J. 107, 109-11.

${ }^{9}$ Compare, e.g., Two Pesos Inc. v. Taco Cabana Inc. [1992] 505 U.S. 763 ("Denying protection for inherently distinctive nonfunctional trade dress until after secondary meaning has been established
} 
saw little action through the twentieth century, ${ }^{10}$ has recently emerged as a popular form of protection for certain types of design. Thus, in varying ways at different times, US law has recognized some forms of legal rights for designers. But the shifting sands, continuing uncertainty, and enduring gaps for short-term designs such as fashion have fueled the ongoing push for sui generis protection. Advocates have pointed to the Community Design System in support of their appeal, but to date, their calls have gone unanswered.

This Chapter explores some of the reasons that the Community Design System has had so little purchase in US debates over design. It begins in Part I with an overview of US law's treatment of design, including the gaps and other features that have fueled calls for legislative reform. Part II then turns to the recent history of design legislation in the US, including the role of the Community Design System in Congressional testimony and deliberations. That history demonstrates that, despite repeated pleas to follow the global trend on design, Congress has so far resisted, for both philosophical and practical reasons. Part III closes with some reflections on whether the US will ever move beyond the current impasse on design.

\section{Design Protection in the US}

The US's ambivalence about new forms of design protection comes from the confluence of three factors: the utilitarian focus of US intellectual property law, a general suspicion of monopoly and preference for competition, and the hybrid nature of design. The first two points are interrelated: with free, competitive markets as the presumptive baseline, intellectual property rights are justified only because they either enable fair competition (trademarks), or provide necessary incentives to induce authorship or invention (copyrights and patents). Absent one of these justifications, the law presumes that market forces will bring the best results for consumers and society. While notions of reward and dessert undoubtedly inform intuitions about intellectual property rights, ${ }^{11}$ they find no basis in the Constitution, from which Congress receives its lawmaking authority. ${ }^{12}$

would allow a competitor, which has not adopted a distinctive trade dress of its own, to appropriate the originator's dress in other markets and to deter the originator from expanding into and competing in these areas."), with Wal-Mart Stores Inc. v. Samara Bros Inc. [2000] 529 U.S. 205, 214 (rejecting possibility of "inherently distinctive" product design trade dress: "Competition is deterred, however, not merely by successful suit but by the plausible threat of successful suit, and given the unlikelihood of inherently source-identifying design, the game of allowing suit based upon alleged inherent distinctiveness seems to us not worth the candle."); see generally J.H. Reichman, Design Protection and the Legislative Agenda [1992] 55 Law and Contemp. Problems 281, 287 (describing a cycle in which "chronic underprotection in industrial property law leads to chronic overprotection in artistic property law, which in turn inspires further reactive reforms of industrial property law tending to reinstate levels of underprotection that will foster renewed appeals to copyright law").

10 See, e.g., Brown, Design Protection, supra note 4 at 1355-57.

11 See, e.g., W. J. Gordon, A Property Right in Self-Expression: Equality and Individualism in the Natural Law of Intellectual Property [1993] 102 Yale L.J. 1540; S. L. Dogan, 'Harms, Benefits, and Justifications in Trademark Law' [2017] (unpublished working draft) (on file with author).

12 The Intellectual Property Clause of the U.S. Constitution provides the basis for patent and copyright law, while the Commerce Clause enables trademark and other unfair competition laws. See U.S. Const. Art. 1, para 8, cl. 8 (authorizing Congress "To promote the progress of science and useful arts, by 
But why, given the role of incentives in US intellectual property law, has Congress resisted the call for additional incentives for design? ${ }^{13}$ It's here that the hybrid nature of design comes into play. Historically, as suggested by the Constitution, US law developed two separate tracks for protection of creative expression and functional innovation. These tracks - copyright and utility patent law - evolved not only to fit their unique subject matter, but also to steer clear of one another's domain. From subject matter to eligibility requirements to infringement to defenses, courts and Congress crafted rules to fit the perceived needs of these distinct types of human creations.

Patent law, for example, gives strong legal rights, ${ }^{14}$ but for a short(er) duration, ${ }^{15}$ and only to inventors who contribute new, non-obvious advances in some useful process or product. ${ }^{16}$ It aims to provide relatively prompt access to functional innovations, so that subsequent innovators have a broad set of building blocks from which to draw. ${ }^{17}$ The more fundamental building blocks - laws of nature, physical phenomena, and abstract ideas - lie beyond even patent law's reach; the law declares them "part of the storehouse of knowledge of all men ... free to all men and reserved exclusively to none."18 Patent law, then, provides muscular rights, but only for eligible inventions and for limited times. All other useful innovations - inventions with expired patents, works that fail patent law's substantive standards, and discoveries of laws of nature, physical phenomena, or abstract ideas - fall into patent's public domain. That public domain, moreover, is guarded to protect against propertization of these interests in some other name. ${ }^{19}$ Patent, in other words, has a strong interest in ensuring free access to the raw materials necessary for useful innovation.

securing for limited times to authors and inventors the exclusive right to their respective writings and discoveries"); Graham v. John Deere Co. of Kansas City [1966] 383 U.S. 1, 9 (noting Thomas Jefferson's rejection of natural rights in favor of a "social and economic rationale of the patent system" that viewed patents as "a reward, an inducement, to bring forth new knowledge"); see also In re Trade-Mark Cases [1879] 100 U.S. 82, 89 (noting Congressional power to regulate the "fraudulent dealing in trade-marks" which "plainly interferes with and thwarts the power and duty of the United States to protect foreign and interstate trade").

${ }^{13}$ See generally J.H. Reichman, supra note 9 at 283 ("Recent studies suggest that industrial design, like computer programs and other forms of applied scientific know-how, cannot yield long-term rewards to innovators if the short-term profits from successful innovation are consistently appropriated by freeriders who do not share the costs and risks of the creative process.").

1435 U.S.C. para 271.

${ }^{15} I d$. at para 154.

${ }^{16} I d$. at paras 101-103.

17 See, e.g., Graham, supra note 85 at 7-9; cf. Sega Enterprises Ltd. v. Accolade Inc. [1992] 977 F.2d 1510,1526 ("In order to enjoy a lawful monopoly over the idea of functional principle underlying a work, the creator of the work must satisfy the more stringent standards imposed by the patent laws."); Specialized Seating Inc. v. Greenwich Indus LP [2010] 616 F.3d 722, 727 (noting goal of trademark's functionality doctrine "to separate the spheres of patent and trademark law, and to ensure that the term of a patent is not extended beyond the period authorized by the legislature").

18 Funk Bros Seed Co. v. Kalo Innoculant Co. [1948] 333 U.S. 127, 130.

${ }^{19}$ Cf. J. E. Cohen, 'Copyright, Commodification, and Culture: Locating the Public Domain', in L. Guibault and P.B. Hugenholtz (eds.) The Future of the Public Domain (Kluwer Law International 2006), 121-166 (exploring historical and theoretical perspectives on the "public domain" in intellectual 
Copyright strikes its balance differently, both for its own intrinsic reasons and out of deference to patent law concerns. It has a long term, ${ }^{20}$ but flimsier rights; ${ }^{21}$ it allows numerous exceptions; $; 2$ and it limits itself to the expressive form, rather than the style, idea, or philosophy underlying an author's work. ${ }^{23}$ All of these features help to balance copyright's short-term goal of incentivizing authorship with its ultimate objective of enabling discourse and advancing knowledge. ${ }^{24}$ But copyright also explicitly defers to patent law's separate concerns, by excluding "any idea, procedure, process, system, method of operation, concept, principle, or discovery" from protection, "regardless of the form in which it is described, explained, illustrated or embodied" in an original work. ${ }^{25}$ Copyright, in other words, avoids giving rights in anything that patent law cares about. It disavows protection of features that "have their final end in application and use." ${ }^{26}$ Authors cannot use copyright to claim rights over patenteligible innovations; nor may they claim elements that patent law has purposely dedicated to the public. Features that have value because they work, in other words, tend to fall outside the scope of copyright. ${ }^{27}$

This division between the expressive and the functional makes sense as a matter of principle and provides a workable standard in many contexts. A chemist who writes a book disclosing a new chemical compound may claim copyright in the book, but must look to patent law for rights in the compound itself. ${ }^{28}$ Useful articles that contain some

property law). Creations in patent's public domain may receive trade secret or other forms of contingent legal protection, but they may not obtain government-granted exclusive rights. See Kewanee Oil Co. v. Bicron Corp. [1974] 416 U.S. 470 (holding that patent law does not preempt state trade secret protection).

2017 U.S.C. para 302.

21 While patent gives the exclusive right to make, use, sell, or import the invention within the statutory term, copyright protects only against copying or other uses that derive directly from the copyright holder's work. It does not protect against the independent creation of similar expression. Id. at para106. 22 See $i d$. at paras 107-122.

${ }^{23}$ Of course, drawing the line between these concepts proves difficult, as Judge Hand observed in Nichols $v$. Universal Pictures Corp. [1930] 45 F.2d 119, 121 (discussing boundary between idea and expression: "Nobody has ever been able to fix that boundary, and nobody ever can.").

24 See U.S. Const., Art. I, sec. 8, cl. 8; see also Sony Corp. of Amer. v. Universal City Studios Inc. [1984] 464 U.S. 417, 429 (noting copyright law's goal of achieving “a difficult balance between the interests of authors and inventors in the control and exploitation of their writings and discoveries on the one hand, and society's competing interest in the free flow of ideas, information, and commerce on the other hand").

2517 U.S.C. para 102(b).

${ }_{26}$ Baker v. Selden [1879] 101 U.S. 99, 104; cf. Star Athletica L.L.C. v. Varsity Brands Inc. [2017] 137 S. Ct. 1002, 1006 (although useful features in themselves cannot claim copyright, "[a]n artistic feature that would be eligible for copyright protection on its own cannot lose that protection simply because it was first created as a feature of the design of a useful article, even if it makes that article more useful"). 27 See Computer Associates Intern. Inc. v. Altai Inc. [1992] 982 F.2d 693, 715 (upholding district court's decision that a feature of a program's structure was "dictated by the nature of other programs with which it was designed to interact and, thus, is not protected by copyright"); but see Oracle Amer. Inc. $v$. Google Inc. [2014] 750 F.3d 1339, 1359-72 (upholding copyright in application program interfaces, despite their function in enabling communications between layers in a computer system). 28 See generally Baker, supra note 25 at 104. 
purely aesthetic feature - say, the pattern on a sofa's fabric, ${ }^{29}$ or a statuette that serves as a lamp base but adds nothing to the utility of the lamp $\mathrm{p}^{30}$ - may receive copyright protection for those features. ${ }^{31}$ In each of these situations, the work contains certain features that contribute to its utility, and others that are purely expressive. The useful features (the chemical compound, the shape and feel of the couch, and the mechanics and illuminating features of the light) fall into patent law's domain, and beyond the reach of copyright. The expressive features, in contrast (the text of the chemistry book, the pattern of the fabric, and the shape and colors of the statuette) may qualify under copyright, but not patent. This divide is neither accidental nor compromising: it reflects a recognition that copyright and patent rights have evolved specifically to fit their subject matter, and a belief that any mismatch between right and subject matter could come with significant social costs. ${ }^{32}$

The problem with design, of course, is that it straddles the patent/copyright divide. In its most general sense, design reflects the "purpose or planning that exists behind an action, fact, or object." 33 While at some points in history "art" was viewed as "something to be applied as an accessory to a design," 34 today "we see the beauty of an artifact - its 'art' ... - as an integral part of its design." 35 That art, moreover, often pervades the design in a way that makes it hard to extricate aesthetics from function, as traditional patent and copyright law demand. Indeed, research has shown that even when they might appear separable, aesthetics and function may have a synergistic relationship because "people perceive more-aesthetic designs as easier to use than less-aesthetic designs - whether they are or not." 36 As a result, granting copyright in the aesthetic aspects of many designs risks giving rights over their functional aspects as well, which would violate the mandate that copyright stay out of patent's territory. It would also defy the normative principle behind that rule: that the public deserves

\footnotetext{
29 See, e.g., Novelty Textile Mills Inc. v. Joan Fabrics Corp. [1977] 558 F.2d 1090.

30 See Mazer v. Stein [1954] 347 U.S. 201.

31 The Copyright Act provides that the design of a "useful article" - one that has "an intrinsic utilitarian function that is not merely to portray the article or to convey information" - may be protected "if, and only to the extent that, such design incorporates pictorial, graphic, or sculptural features that can be identified separately from, and are capable of existing independently of, the utilitarian aspects of the article." 17 U.S.C. para 101.

32 See, e.g., Herbert Rosenthal Jewelry Corp. v. Kalpakian [1971] 446 F.2d 738, 741 ("Obviously a copyright must not be treated as equivalent to a patent lest long continuing private monopolies be conferred over areas of gainful activity without first satisfying the substantive and procedural prerequisites to the grant of such privileges.").

${ }^{33}$ Design, Oxford English Dictionary Online, <https://en.oxforddictionaries.com/definition/design> accessed 26 September 2017.

${ }^{34}$ C. Fiell and P. Fiell, The Story of Design: From the Paleolithic to the Present (The Monacelli Press 2016).

35 Id.; see also Star Athletica L.L.C. v. Varsity Brands Inc. [2017] 137 S. Ct. 1002, 1034 (Breyer, J., dissenting) ("great industrial design may well include design that is inseparable from the useful article - where, as Frank Lloyd Wright put it, 'form and function are one"') (quoting F. Wright, Frank Lloyd Wright: An Autobiography 146 (reprint 2005) [1943]); M. P. McKenna and K. J. Strandburg, 'Progress and Competition in Design' [2013] 17 Stan. Tech. L. Rev. 1.

36 See W. Lidwell et al., Universal Principles of Design (Rockport Publishers 2003) (describing this phenomenon as the "aesthetic-usability effect").
} 
broad and prompt access to the building blocks of functional innovation. ${ }^{37}$ Denying protection, on the other hand, deprives designers of copyright's rewards (and incentives) for their original expression.

This tension - between the desire to incentivize original expression and caution about tying up functional tools - has plagued copyright since Congress first extended protection to works of applied art in 1909.38 The current Copyright Act allows protection of expressive features of functional objects so long as those "features ... can be identified separately from, and are capable of existing independently of, the utilitarian aspects of the article." ${ }^{39}$ This "separability" doctrine has perplexed the courts, who have struggled with what it means for a feature to be separately "identifi[able]" despite its physical embodiment in a useful object. ${ }^{40}$ Star Athletica $v$. Varsity Brands, the Supreme Court's recent foray into separability, did little to clarify things; in upholding the copyright on the surface decorations on cheerleading uniforms, the Court left unanswered questions about how it would handle threedimensional objects whose function is inextricably melded with their form. On its face, the Court's standard for separability appears broad enough to include virtually any visually appealing object: "a feature of the design of a useful article is eligible for copyright if, when identified and imagined apart from the useful article, it would qualify as a pictorial, graphic, or sculptural work either on its own or when fixed in some other tangible medium." ${ }_{11}$ Yet the Court makes clear that its rule would not allow copyright in either the "shape, cut, and physical dimensions of the cheerleading uniforms," 42 or in "a shovel as a shovel." 43 Star Athletica thus fails to resolve the ongoing uncertainty about copyright protection for three-dimensional design. Because

\footnotetext{
${ }^{37}$ See generally Lotus Development Corp. v. Borland Intern. Inc. [1995] 49 F.3d 807, 819 (J. Boudin, concurring) ("It is no accident that patent protection has preconditions that copyright protection does not - notably, the requirements of novelty and non-obviousness - and that patents are granted for a shorter period than copyrights."); cf. Jay Franco and Sons Inc. v. Franek [2010] 615 F.3d 855, 859. The implications for patent-eligible and non-patent eligible features are related but distinct. For patenteligible features, denying copyright protection drives the inventor to the form of protection better calibrated for functional inventions, with its disclosure requirements and relatively short term. For nonpatent-eligible useful features, denying copyright protection wards against an end-run of patent requirements, which could ironically lock up non-inventive building blocks for a time far exceeding the patent term. See Baker v. Selden [1879] 101 U.S. 99, 102 (noting concerns over the use of copyright law to circumvent patent law's substantive standards, short term, and disclosure requirements).

38 See Mazer v. Stein [1954] 347 U.S. 201, 208-14.

3917 U.S.C. para 101.

40 See generally Star Athletica, supra note 35 at 1018 and n. 1 (J. Ginsburg, concurring) ("Courts 'have struggled mightily to formulate a test' for the separability analysis”) (quoting Star Athletica L.L.C. v. Varsity Brands Inc. [2015] 799 F.3d 468, 484); see also Mazer v. Stein [1954] 347 U.S. 201.

41 Star Athletica, supra note 35 at 1012 (emphasis added) and 1014 ("An artistic feature that would be eligible for copyright protection on its own cannot lose that protection simply because it was first created as a feature of the design of a useful article, even if it makes that article more useful."). 42 Id. at 1016 ("our test does not render the shape, cut, and physical dimensions of the cheerleading uniforms eligible for copyright protection," presumably because they fail the separability test). 43 Id. at 1013 and n.2 (noting that if a "shovel included any artistic features that could be perceived as art apart from the shovel, and which would qualify as protectable pictorial, graphic, or sculptural works on their own or in another medium, they too could be copyrighted but a shovel as a shovel cannot") (emphasis added).
} 
the case involves only surface ornamentation, the opinion avoids the fundamental question of how to protect expression while respecting patent law's commitment to its public domain.

While the ongoing struggle over the domains of patent and copyright does not speak directly to the merits of sui generis design protection, it offers some hints about the challenges confronting design legislation in the United States. Generally, it demonstrates a longstanding assumption in US law that the "functional" and the "expressive" lend themselves to different forms of legal protection that are calibrated to their needs. More specifically, it reflects a discomfort with exclusive rights in useful features, except when they have undergone the rigors of patent examination. When combined with the general presumption in favor of access and competitive markets, these factors provide a powerful force for the status quo and against new rights.

These same factors have shaped the development of trademark protection for product design. US trademark law protects product features, such as shape and color, whose consistent usage over time has led consumers to associate them with a single source. ${ }^{44}$ Unlike patent and copyright law, however, US trademark law does not view incentivizing such features as its raison d'être. ${ }^{45}$ The law does not aim to encourage investment in appealing marks, nor does it treat marks as having any intrinsic social value apart from their informational function. ${ }^{46}$ Instead, US trademark law views marks as informational devices, and protects them to guard against misinformation in markets, with the ultimate goal of making markets more competitive. ${ }^{47}$ It's not that trademark law has nothing to do with incentives or rewards, but the incentives and rewards of trademark focus on the trademark holder's investment in its reputation, rather than investment in the creation of a work (i.e., a trademark) that itself functions or entertains. ${ }^{48}$ The law does not - at least deliberately - seek to incentivize the creation of marks based on their aesthetic appeal, function, or other inherent value. It seeks to enable informed and competitive markets.

Given trademark law's focus on competition, it shares (and amplifies) copyright's skepticism about locking up features that enhance product function. In trademark law, this skepticism plays out through the functionality doctrine, which bars

\footnotetext{
44 See Wal-Mart Stores Inc. v. Samara Bros. Inc. [2000] 529 U.S. 205, 212-16.

${ }^{45}$ See, e.g., TrafFix Devices Inc. v. Marketing Displays Inc. [2001] 532 U.S. 23, 34 ("The Lanham Act does not exist to reward manufacturers for their innovation in creating a particular device; that is the purpose of the patent law and its [limited] period of exclusivity.”).

46 The law acknowledges that trademarks (particularly trade dress) often make the product more attractive; that alone does not justify denial of trademark protection. "The chief difficulty is distinguishing between designs that are fashionable enough to be functional and those that are merely pleasing." Jay Franco and Sons Inc. v. Franek [2010] 615 F.3d 855, 860.

${ }^{47}$ See S. L. Dogan and M. A. Lemley, 'The Merchandising Right: Fragile Theory or Fait Accompli?' [2005] 54 Emory L.J. 461 at 467 ("Trademark law ... aims to promote more competitive markets by improving the quality of information in those markets.").

$48 I d$. at 468 ("Trademark law quite deliberately does not serve" incentive-related goals; "both its philosophy and its structure reject the notion that trademark rights should serve as either an inducement or a reward for the creation of product features that have inherent - as opposed to sourceidentifying - value.”).
} 
trademark protection for any feature that is "essential to the use or purpose of [a] device" or "affects the cost or quality of the device." 49

For a time in the late twentieth century, some courts interpreted functionality narrowly, using it to deny protection only for features that had no effective substitutes. Thus, features that contributed to a product's function or ease of use could be protected, as long as the trademark holder could point to alternative ways to accomplish that function in competitors' products. ${ }^{50}$ This "competitive necessity" approach viewed the purpose of functionality as enabling competitive markets; as long as a particular feature was not essential to competition, the reasoning went, it made sense to protect it if it played any signaling role to consumers. ${ }^{51}$

In TrafFix v. Marketing Displays, ${ }^{52}$ however, the Supreme Court rejected the competition-focused view of functionality in favor of one that blended competition concerns with patent-deference considerations. The plaintiff in TrafFix had sought trade dress protection for a road sign's "dual spring device," which enabled the sign to sway in the wind without falling over. The court of appeals had found the spring device non-functional, because competitors had viable alternatives, including the option of using the same spring and covering it up. ${ }^{53}$ The Supreme Court reversed, in an opinion that rejected the competitive necessity test as a "comprehensive definition" of functionality. ${ }^{54}$ While endorsing competitive necessity in cases involving aesthetic product features, ${ }^{55}$ the Court found it inapt for features that are "essential to the use or purpose" of a product or "affect[its] cost or quality." 56 For such features, it is irrelevant whether alternatives exist; the feature cannot serve as a trademark. ${ }^{57}$ In reaching this conclusion, the Court emphasized the same normative principle that drives the patent/copyright divide: the notion that patent law - and not copyright or trademark - is the sole arbiter of exclusive rights in functional innovation. ${ }^{58}$

\footnotetext{
49 TrafFix, supra note 45 at 33.

50 See, e.g., Marketing Displays Inc. v. TrafFix Devices Inc. [1999] 200 F.3d 929, 940 (holding that a dual-spring mechanism at the base of a road sign could receive trademark protection, because competitors could use the same springs but cover them to make the feature not visible to consumers). 51 See, e.g., In re Morton-Norwich Prods. Inc. [1982] 671 F.2d 1332, 1337 ("when a design is 'nonfunctional,' the right to compete through imitation gives way, presumably upon balance of that right with the originator's right to prevent others from infringing upon an established system of trade identification").

52 TrafFix Devices Inc. v. Marketing Displays Inc. [2001] 532 U.S. 23.

53 Marketing Displays, 200 F.3d at 940.

54 TrafFix, 532 U.S. at 33.

55 See id. at 32-33 (citing Qualitex Co. v. Jacobson Products Co. [1995] 514 U.S. 159, 165).

56 Id. at 33.

${ }^{57}$ See $i d$. (aesthetic functionality (and the availability of alternatives) applies only when the feature has no "bearing on the use or purpose of the product or its cost or quality").

58 Id. at 34 ("The Lanham Act does not exist to reward manufacturers for their innovation in creating a particular device; that is the purpose of the patent law and its period of exclusivity.... Whether there is a utility patent or there has been no utility patent at all, a product design which has a particular appearance may be functional because it is 'essential to the use or purpose of the article' or 'affects the cost or quality of the article."); see also McKenna and Strandburg, supra note 35 at 23 ("Because 'unpatented design and utilitarian conceptions' provide 'the baseline of free competition' that produces
} 
For the most part, post-TrafFix courts have taken the Supreme Court at its word and rejected trade dress claims to elements that contribute to a product's function, distinguishing between such features (which are always functional) and "arbitrary, incidental, or ornamental aspects of features" (which may be functional under aesthetic functionality's competition-focused standard). ${ }^{59}$ Unless a trademark claimant can point to a "feature that contributes no demonstrable benefit to the operation or efficiency of the designed product,"60 it will likely fail the TrafFix functionality test. As a result, like copyright, trademark law offers few options for designs whose aesthetic appeal blends inextricably with function.

With copyright protection unclear and trademark protection unattainable for many valuable design features, a third option - design patent - has recently emerged as a viable alternative for many types of design. US design patent law allows protection for "any new, original and ornamental design for an article of manufacture." 61 Design patents last for fifteen years from the date of grant. ${ }^{62}$ The process of obtaining a design patent resembles that of utility patents: the applicant submits an application with the Patent and Trademark Office, which subjects it to a substantive review. Like utility patents, design patents require novelty ${ }^{63}$ and non-obviousness ${ }^{64}$ of the design. Unlike utility patents, however, design patents cover only "ornamental" features of products. ${ }^{65}$ Design patents thus cover completely different features than utility patents. "While utility patents protect 'the way an article is used and works,' design patents protect 'the way an article looks." 66 Of course, it's no easy task to distinguish between the two; as discussed below, design patent's own functionality doctrine attempts to mediate between form and function. In contrast to copyright and

the 'ordinary innovation' upon which the patent incentive builds, trade dress law subordinates its static competition goals to patent law's dynamic goals.”) (internal quotations omitted).

59 See, e.g., Groeneveld Transport Efficiency Inc. v. Lubecore International Inc. [2013] 730 F.3d 494, 505 (affirming lower court's finding of functionality when "all the elements of [the claimed] pump are there for some practical benefit or reason," and when trademark claimant had not presented evidence of a "purely ornamental feature that contributes no demonstrable benefit to the operation or efficiency of the designed product") (internal quotations omitted); Christian Louboutin S.A. v. Yves Saint Laurent America Holdings Inc. [2012] 696 F.3d 206, 219-20 ("when the aesthetic design of a product is itself the mark for which protection is sought, we may also deem the mark functional if giving the markholder the right to use it exclusively 'would put competitors at a significant non-reputation-related disadvantage") (quoting Qualitex, 514 U.S. at 165).

60 Groeneveld, id. at 505.

6135 U.S.C. para 171. Design patents must also satisfy the general requirements for utility patents, including non-obviousness, novelty, and disclosure. Id.

62 Id. at para 173. For applications filed before May 13, 2015, the term was fourteen years from the date of grant.

63 Id. at para 102.

64 Id. at para 103.

65 Id. at para171(a). Patented designs must also be "original," but the originality requirement is rarely at issue. See generally Int'l Seaway Trading Corp. v. Walgreens Corp.[2009] 589 F.3d 1233, 1238 (“The purpose of incorporating an originality requirement is unclear; it likely was designed to incorporate the copyright concept of originality-requiring that the work be original with the author...").

66 Burstein, supra note 8 at 112 (quoting U.S. Dep't of Commerce, Patent and Trademark Off., Manual of Patent Examining Procedure para 1502.01 [9th ed., Rev. 07.2015, Nov. 2015]). 
trademark law, however, design patent offers a form of protection that is arguably better suited to aesthetically appealing industrial design, because it expires after a relatively short duration.

For most of the twentieth century, design patents saw little action because of their reputation as expensive, cumbersome, substantively demanding, and narrowly construed. ${ }^{67}$ Since the turn of the century, however, design patents have enjoyed a renaissance, with soaring application numbers and high profile infringement suits. ${ }^{68}$ Although many factors have contributed to this shift, three developments proved critical: trademark law's retreat from broad design protection, ${ }^{69}$ a softening of the rigorous standards for obtaining a design patent, ${ }^{70}$ and a Federal Circuit decision that eased the burden of proving design patent infringement. ${ }^{71}$ Together, these changes have led to an explosion in design patent acquisition and litigation.

\footnotetext{
67 See, e.g., Reichman, supra note 13 at 286 ("the design patent law still requires a full examination of the prior art, which makes it too costly, slow and cumbersome for the bulk of the commercial designs competing in today's fast-paced consumer markets"); Brown, supra note 4 at 1356 (describing design patent as "a Cinderella who never goes to the ball," and listing a number of "reasons why design patents are held in low esteem"); P. J. Saidman, 'The Crisis in the Law of Designs' [2007] 89 J. Pat. and Trademark Off. Soc'y 301; see also Burstein, Costly Designs, supra note 8 at 109-11. 68 See U.S. Patent Statistics Chart, Calendar Years 1963-2015, U.S. Patent Statistics Chart, <https://www.uspto.gov/web/offices/ac/ido/oeip/taf/us_stat.htm> accessed 28 September 2017 (showing increase from 18,292 design patent applications in 2000 to 39,097 in 2015); see also Samsung Electronics Co. v. Apple Inc. [2016] 137 S. Ct. 429, 433-34 (describing history of litigation between Apple and Samsung over iPhone design patents); Crocs v. ITC [2010] 598 F.3d 1294; see generally P. Lee and M. Sunder, 'Design Patents: Law Without Design', [2013] 17 Stanford Tech. L. Rev. 277, 278-79. 69 The retreat occurred in two steps. The Supreme Court's 2000 decision in Wal-Mart Stores Inc. $v$. Samara Bros. Inc. [2000] 529 U.S. 205, limited product-design trade dress protection to features that have acquired secondary meaning among consumers. Four years later, the Court decided TrafFix, with its aggressive approach to functionality. See supra notes 52-58. Together, these decisions substantially narrowed the universe of product features that could qualify for trade dress protection.

70 See generally Burstein, supra note 8 at 139-141 ("The U.S. Court of Appeals for the Federal Circuit, which has had exclusive appellate jurisdiction in design patent cases since 1982, has quietly eroded the statutory requirements for design patentability to the point where it is extremely difficult for the PTO to reject design patent applications on the merits."); S. Burstein, 'Moving Beyond the Standard Criticisms of Design Patents' [2013] 17 Stan. Tech. L. Rev. 305 at 324-28.

${ }^{1}$ Egyptian Goddess Inc. v. Swisa Inc. [2008] 543 F.3d 665 (en banc). In Egyptian Goddess, the appeals court abandoned the "point of novelty" requirement for design patent infringement, thus allowing a showing of infringement based on the overall appearance of two designs. Id. at 670 ("[I]f, in the eyes of an ordinary observer, giving such attention as a purchaser usually gives, two designs are substantially the same, if the resemblance is such as to deceive such an observer, inducing him to purchase one supposing it to be the other, the first one patented is infringed by the other.").
} 
While its rise is still nascent, under-theorized, ${ }^{72}$ and largely untested, ${ }^{73}$ design patent may have the staying power that copyright and trademark lack for protection of product design. For one thing, unlike these other forms of intellectual property, design patent has a relatively short term, ${ }^{74}$ which reduces (but does not eliminate) the overall social costs of granting rights in product features. It has an examination process and qualitative standards that at least theoretically weed out non-novel or obvious variations on existing art. ${ }^{75}$ Its disclosure requirement provides notice of the existence and scope of design patent claims. ${ }^{76}$ And design patent has a functionality standard that, like copyright and trademark's versions, shows some deference to utility patent as the exclusive domain for useful innovation. Design patent's functionality doctrine is somewhat narrower than trademark's, excluding only those features that are "dictated by function." 77 The Federal Circuit, moreover, has repeatedly upheld "narrow" design patents that consist of purportedly ornamental combinations of functional elements. ${ }^{78}$ Design patent law thus allows claims that trademark and copyright would likely eschew. ${ }^{79}$ Even so, the combination of moderate utility patent deference with limited terms suggests that design patents are better calibrated than either trademark or copyright law to protect the overall ornamental appearance of designs that blend form with function.

72 This is changing fast; numerous scholars have turned their attention to design patents in the past decade. See, e.g., J. J. DuMont and M. D. Janis, 'The Origins of American Design Patent Protection' [2013], 88 Ind. L.J. 837; S. Burstein, 'The Patented Design' [2015] 83 Tenn. L. Rev. 161; S. Burstein, 'Visual Invention' [2012] 16 Lewis and Clark L. Rev. 169, 175; J. M. Mueller and D. Harris Brean, 'Overcoming the "Impossible Issue" of Nonobviousness in Design Patents' [2011] 99 Ky. L.J. 419; and the articles published in Volume 17 of the Stanford Technology Law Review [2013]

$<$ https://journals.law.stanford.edu/sites/default/files/stanford-technology-lawreview/online/vol17issue1_0.pdf> accessed 24 November 2017.

${ }^{73}$ Although the Federal Circuit has issued plenty of design patent opinions in recent years, the Supreme Court has not decided a substantive design patent case since the 1800s. See Smith v. Whitman Saddle Co. [1893] 148 U.S. 674. Its only recent design patent opinion involved damages, and the Court reversed the Federal Circuit's plaintiff-friendly interpretation of the damages provision in the design patent law. See Samsung v. Apple, 137 S. Ct. 429.

7435 U.S.C. para 173 (providing for term of fifteen years from date of grant).

${ }^{75} \mathrm{Id}$. at paras $171,102,103$.

${ }^{76}$ Cf. J. Bessen and M. J. Meurer, Patent Failure (Princeton University Press 2009) ("Property can fail when boundary information is not publicly accessible," and "when the boundaries of the rights are not clear and predictable.").

77 See, e.g., Ethicon Endo-Surgery Inc. v. Covidien Inc. [2015] 796 F.3d 1312, 1334.

${ }^{78}$ See, e.g., id. at 1334 ("Thus, although the Design Patents do not protect the general design concept of an open trigger, torque knob, and activation button in a particular configuration, they nevertheless have some scope - the particular ornamental designs of those underlying elements."); Sport Dimension Inc. v. Coleman Co. Inc. [2016] 820 F.3d 1316, 1323 (agreeing with district court that the armbands and side torso tapering of life jackets were functional, but nonetheless concluding that the court should have included these features in evaluating infringement: "the armbands and side torso tapering serve a functional purpose, so the fact finder should not focus on the particular designs of these elements when determining infringement, but rather focus on what these elements contribute to the design's overall ornamentation").

${ }^{79}$ It remains to be seen whether Star Athletica will apply broadly to three-dimensional features of industrial designs; if it does, it may result in significant overlap between copyright and design patent, because the Supreme Court's emphasis on whether a feature could be "imagined" apart from the useful article comes close to the Federal Circuit's inquiry into the "overall ornamentation" reflected in an industrial design. See Star Athletica, 137 S. Ct. at 1012; see also Sport Dimension, 820 F.3d at 1316. 
Better calibrated, of course, does not mean perfect, and as design patents have surged in popularity, critics have warned that their proliferation may cause thickets and other anticompetitive effects. ${ }^{80}$ These effects multiply when courts allow design patent-holders to leverage their periods of exclusivity into potentially perpetual trade dress rights. ${ }^{81}$ These concerns suggest that courts should shape design patent law with caution; in particular, they should incorporate rigor into design patent standards, and reconsider the wisdom of allowing trademark protection for previously patented designs. ${ }^{82}$ But at least compared to trademark and copyright, design patent is better tailored to its subject matter; and as Sarah Burstein has argued, the expense and effort associated with design patents may well weed out some trivial innovations and reduce the risk of thickets. ${ }^{83}$ In any event, in the long arc of US intellectual property history, the renewed interest in design patents has relieved some of the pressure toward new forms of protection for design.

Design patent's newfound popularity, however, has not entirely quelled the call for sui generis design rights, particularly in the area of fashion. Critics contend that, even if design patents provide adequate protection for some types of design, they do not meet the needs of fast-moving industries like fashion. ${ }^{84}$ Design patents take an average of over nineteen months to issue - an eternity for an industry that introduces new designs every season. ${ }^{85}$ And prosecuting a design patent requires a significant financial investment. ${ }^{86}$ As a result, while large fashion houses have turned to design patents to protect "staple items" such as shoes and purses, ${ }^{87}$ smaller, more garment-

\footnotetext{
80 See, e.g., Burstein, supra note 8 at 129-132 (describing social costs associated with bad design patents); Lee and Sunder, supra note 68 at 290-293.

${ }^{81}$ Because design patent owners have a guaranteed period of exclusivity in the sale of products bearing their design, they can often demonstrate that the design has acquired secondary meaning at the expiration of the design patent term. See Burstein, supra note 80 at 131. And many courts have (erroneously, in my view) held that a feature's non-functionality under design patent law means that it is non-functional as a matter of trademark law. See generally S. Burstein, 'Commentary: Faux Amis in Design Law' [2015] 105 Trademark Rep. 1455, 1458-59 (criticizing this line of cases); see also M. P. McKenna, '(Dys)functionality' [2011] 48 Hous. L. Rev. 823, 843.

${ }^{82}$ McKenna and Burstein have demonstrated the folly - and the costs - of the current approach. See Burstein, supra note 81; McKenna, supra note 81.

${ }^{83}$ Burstein, supra note 8.

${ }^{84}$ See, e.g., Hemphill and Suk, supra note 1 at 1150 and n.10; S. Scafidi, 'Intellectual Property and Fashion Design', in P. K. Yu (ed) Intellectual Property and Information Wealth: Copyright and Related Rights (Greenwood Publishing Group 2006) at 115.

${ }^{85}$ See Data Visualization Center: Patents Dashboard: Design Traditional Total Pendency, U.S. Patent and Trademark Office, <https://www.uspto.gov/dashboards/patents/main.dashxml?CTNAVID=1006> accessed 28 September 2017.

${ }^{86}$ Basic design patent filing fees come to $\$ 760$ for large entities, $\$ 380$ for small entities, and $\$ 190$ for micro-entities. See USPTO Fee Schedule, U.S. Patent and Trademark Office,

$<$ https://www.uspto.gov/learning-and-resources/fees-and-payment/uspto-fee-schedule> accessed 28 September 2017. Because most applicants also hire attorneys or patent agents to prepare design drawings and to prosecute their applications, overall fees can run into thousands of dollars.

${ }^{87}$ See The Fashion Law, 'Currently Trending in Fashion: Design Patents',

$<$ http://www.thefashionlaw.com/home/currently-trending-in-fashion-design-patents $>$ accessed 24 November 2017.
} 
focused designers have less to gain from the design patent regime. And even wellheeled designers complain of design patent's inadequacy in protecting against "fastfashion" copying, through which "thousands of inexpensive copies of a new design can be produced, from start to finish, in six weeks or less." 88 These industry-specific concerns provide both the engine and the backdrop for the perennial push for sui generis fashion legislation.

\section{US Design Legislation and the Role of the Community Design System}

Over the past decade, the United States Congress has considered several different iterations of design legislation, with a particular emphasis on fashion. ${ }^{89}$ While specifics vary, all of the bills would extend some form of short-term protection to original fashion designs. ${ }^{90}$ Early bills required prompt registration, and allowed for a three-year term; 91 more recent legislation would offer automatic protection for three years after a design is made available to the public. ${ }^{92}$ Drafters have also tweaked the standards for eligibility and infringement. ${ }^{93}$ Although the two most recent bills have made it through the Senate Judiciary Committee and proceeded to the Senate floor, ${ }^{94}$ none has yet seen a vote by either the Senate or the House.

The witness testimony and lawmaker commentary about these bills offer insight into why Congress has not (yet) followed Europe in adopting a new design law. It's not for lack of awareness of the Community Design System and similar laws around the world. To the contrary, the global trend toward design protection plays a recurrent role in the legislative debate. ${ }^{95}$ Instead, the record shows legislators intuitively drawn

\footnotetext{
${ }^{88}$ Hemphill and Suk, supra note 1 at 1171.

89 See, e.g., A Bill to Amend Title 17, United States Code, to Provide Protection for Fashion Design, H.R. 5055, 109th Cong., 2d Sess. (introduced Mar. 30, 2006) (“H.R. 5055”); Design Piracy Prohibition Act, S.1957, 110th Cong., 1st Sess. (introduced Aug. 2, 2007); Design Piracy Prohibition Act, H.R. 2033, 110th Cong., 1st Sess. (introduced April 25, 2007); Innovative Design Protection and Piracy Prevention Act, S. 3728, 111th Cong., 2d Sess. (introduced Aug. 5, 2010) ("IDPPPA"); Innovative Design Protection Act of 2012, S. 3523, 112th Cong., 2d Sess. (introduced Sept. 10, 2012) ("IDPA").

90 Each of the Acts would amend the Copyright Act by broadening an existing sui generis provision focused on vessel hulls. See H.R. 5055, supra note 89 at para1; see also 17 U.S.C. para 1301(a).

91 H.R. 5055, supra note 89 at para1 (c-e).

92 See IDPPA, supra note 89 at para $2(\mathrm{~d}, \mathrm{f})$.

${ }^{93}$ Compare, e.g., H.R. 5055 (providing protection to any original "fashion design"), with IDPPPA para 2(a)(7](B) (limiting protection to designs that "provide a unique, distinguishable, non-trivial and nonutilitarian variation over prior designs for similar types of articles").

${ }^{94}$ See IDPPPA (placed on Senate legislative calendar Dec. 6, 2010); S. Rep. No. 112-259 [2012].

95 See, e.g., S. Rep. No. 112-259 at 2 [2012] ("In terms of the protections available to designers, ... the United States remains at a disadvantage compared to the European Union, with which we compete to be the global center of the fashion industry."); Innovative Design Protection and Piracy Prevention Act, Hearing Before the Subcomm. on Intellectual Property, Competition, and the Internet [2011] 112th Cong., 1st Sess. at 1 ("2011 Hearing”) (Statement of Rep. Bob Goodlatte) ("Most industrialized nations provide legal protection for fashion designs. However, in the United States, the world's leader in innovation and creativity, fashion designs are not protected by traditional intellectual property regimes.”); Design Law - Are Special Provisions Needed to Protect Unique Industries?: Hearing Before the Subcomm. on Courts, the Internet, and Intellectual Property [2008] 110th Cong., 2d Sess., at 8 ("2008 Hearing”) (Statement of William T. Fryer, III) (describing "design protection - protection when you go
} 
to the idea of protecting designers, but grappling with the fit between these fashion bills and the normative goals of US intellectual property law. Equivocal economic evidence, concerns about chill, and definitional questions that have long plagued design protection have sowed doubt about the wisdom of the design bills; as a practical matter, the relative modesty of the fashion industry's political footprint no doubt contributes to the inertia.

\section{Equivocal economics.}

Incentives. As discussed above, the US intellectual property tradition views intellectual property rights through a utilitarian lens, which emphasizes social welfare considerations over rewards to creators. As a result, although advocates of design legislation routinely appeal to intuitive notions of fairness, their success depends on their ability to persuade legislators that society - not just designers - will be better off with design protection than without it. Incentives lie at the heart of their pitch: without design protection, the argument goes, rip-offs will leave designers unable to capture the full value of their work. The resulting underinvestment in design will deter future designers from entering the field, leaving consumers worse off and harming the national economy.

Not surprisingly, proponents of design legislation and their Congressional sponsors have relied heavily on this incentives-based narrative. Representative Bob Goodlatte, a sponsor of the 2011 Innovative Design and Piracy Protection Act, extolled the need for fashion protection to provide the "incentive ... necessary to maintain America's position as the world leader in innovation." 96 Witnesses warned that current fashion copying "undermines incentives" 97 and predicted that, "in the long term, lack of protection will shrink American businesses and provoke the loss of American jobs."98

Despite the visceral appeal of this incentives story, however, critics contend that it relies on intuition and anecdote rather than hard economic data. Indeed, Christopher Sprigman and Kal Raustiala have argued that knock-offs and other imitations benefit the fashion industry by creating trends, which drive demand for fashion and thus

\footnotetext{
into the market, the entry-level protection" as "a trend across the world," and mentioning Europe specifically); id. at 19 (Statement of Rep. William D. Delahunt) ("Europe, Japan and India have protection for 15-25 years for registered designs and we have nothing."); id. at 22 (Statement of Narcisco Rodriguez) ("Other developed countries such as Europe, Japan and India all provide 15 to 20 years of protection for fashion designs. Since there is no protection in the U.S., companies have emerged with piracy as their business model.").

962011 Hearing, supra note 95 at 1 (Statement of Rep. Bob Goodlatte).

${ }_{97} \mathrm{Id}$. at 15 (Statement of Jeannie Suk) (contending that "blatant replication ... most directly takes profits from the original producer and thus most undermines the incentive to create that federal copyright law aims to foster").

${ }^{98}$ Id. at 8 (Statement of Lazaro Hernandez); see also id. at 9 ("Without this legislation, the creativity and innovation that has put American fashion in a leadership position will dry up.”).
} 
sustain a thriving market. 99 As Sprigman testified before Congress, "For fashion, copying does not deter innovation. It speeds it up."100 Other scholars disagree. Scott Hemphill and Jeannie Suk, for example, distinguish between imitation - which fosters innovation and supports a vibrant fashion economy - and exact, fast-fashion copies which, they contend, drain revenues and dampen incentives for designers. ${ }^{101}$

Whatever the merits of these competing visions of the design industry, advocates of design protection have to grapple with one uncomfortable truth: the industry has flourished without the legal protection that they seek. Indeed, the industry's own witnesses celebrate the explosion of fashion design in the US. ${ }^{102}$ As designer Narcisco Rodriguez testified in 2008, "More and more young Americans are going into fashion, and America now leads the world in fashion design." 103 This does not, of course, disprove the notion that designers lose money from copying, or that greater protection might draw even more young Americans into the industry. But it does call into question the premise upon which the industry's utilitarian argument relies: that lack of protection will result in market failure and underinvestment in fashion design. ${ }^{104}$

A similar disconnect appears in proponents' arguments regarding licensing. To support their claim that the bills will benefit consumers, advocates predict that legal protection will enable designers to license their work to low-cost manufacturers, who will then sell them at affordable prices. ${ }^{105}$ Again, however, the industry's own witnesses undermine this claim by showing that such licensing already occurs. ${ }^{106}$ While a legal right would give designers more leverage in licensing negotiations (and may well increase prices for consumers), advocates have yet to make the case that it is essential. Indeed, licensing to affordable manufacturers could well decrease in a world

\footnotetext{
99 See K. Raustiala and C. J. Sprigman, 'The Piracy Paradox: Innovation and Intellectual Property in Fashion Design' [2006] 92 Va. L. Rev. 1687.

1002011 Hearing, supra note 95 at 75 (Statement of Christopher Sprigman).

101 See Hemphill and Suk, supra note 1.

102 See also 2011 Hearing, supra note 95 at 6 (Statement of Lazaro Hernandez) (noting that "fashion has grown to a $\$ 340$ billion industry in the US").

1032008 Hearing, supra note 95 at 24 (Statement of Narcisco Rodriguez).

104 See also Raustiala and Sprigman, supra note 99; 2008 Hearing, supra note 95 at 30 (Statement of Steve Maiman) ("Over many years, the fashion industry has done very well. It has grown into a huge, competitive, innovative and vibrant industry, all without the help or interference from this particular type of copyright law.").

105 E.g., 2011 Hearing, supra note 95 at 8 (Statement of Lazaro Hernandez) (contending that design rights will facilitate licensing deals); $i d$. at 14 (Statement of Jeannie Suk).

106 E.g., 2011 Hearing, supra note 95 at 8 (Statement of Lazaro Hernandez) (describing "American designers who have collaborated" with low-cost retailers, including "Isaac Mizrahi at Target, Isabel Toledo at Payless, Norma Kamali at Wal-Mart, Mary Kate and Ashley Olsen at JC Penney, Billy Reid at J.Crew, Diane von Furstenberg at Gap and Vera Wang at Kohl's. These stores have all seen the value of making the works of American designers available in their stores through licensing deals so that designers get paid for their innovation and creativity"); id. at 14 (Statement of Jeannie Suk) ("Many extremely talented designers ... have partnered with high-volume retailers, such as Target and HandM, to offer their designs in large numbers at a low price. The ID3PA encourages this kind of partnership because this allows designers to profit from the creative labor they invest in their original designs.").
} 
of exclusive design rights; it seems plausible that the threat of competition from copyists may have brought designers to the table in the first place.

Compounding these questions about the incentive effects of design protection are concerns about its costs.

Deadweight loss and increased consumer prices. As with any form of exclusive rights, design protection would likely raise the price that consumers pay to access some appealing designs. ${ }^{107}$ Of course, the prospect of such supra-competitive pricing comes with the territory in intellectual property; it generates the profits that give rightsholders reason to invest in creating valuable works. But if creators would innovate even without the promise of these excess profits, the higher prices cause unnecessary deadweight loss and a wealth transfer away from consumers.

Definitional problems and the risk of chill. Even if the incentive story indicated a clear risk of market failure and a need for protection for design, design protection raises difficult definitional questions that risk chilling legitimate conduct and suppressing competition. These problems were especially acute in early versions of the design legislation, which adopted broad definitions of protected subject matter and infringement. ${ }^{108}$ Later bills narrowed the right's subject matter and scope, limiting protection to "unique, distinguishable, non-trivial and non-utilitarian variation[s]" on existing designs and defining infringing works as copies that are "substantially identical" to the "overall visual appearance" of the protected design. ${ }^{109}$ Despite these clarifications, experience suggests that determining the validity and scope of design rights will prove fact-intensive and often indeterminate. The lack of a registration requirement compounds these notice problems, leaving would-be imitators with three choices: hiring counsel to evaluate the risk of an infringement suit, plunging forward and risking litigation, or choosing not to copy. ${ }^{110}$ Any of these choices raises costs, which will inevitably pass on to consumers.

If the need for design incentives were sufficiently strong, of course, it could overcome these objections. In fact, though, the economic record provides meager support for the fashion industry's claim that design protection will increase overall social welfare, the prerequisite for new intellectual property rights in the US. The 2012 bill made it to the Senate floor despite these shortcomings, but progressed no further. Undoubtedly, the equivocal economic picture at least partially explains why. Indeed, some Senators on the Judiciary Committee (where the bill was introduced) opposed it precisely because of concerns that it could "upset a well-functioning market" and harm

\footnotetext{
107 See S. Rep. No. 112-259 at 10 [2012] (Minority Views of Senators Coburn, Cornyn, Lee, and Sessions).

108 The 2006 legislation would have prohibited the making or importing of any design substantially similar to an original design. See H.R. 5055, 109th Cong., 2d Sess. [2006]; 17 U.S.C. para 1301 (protecting any original fashion design - defined as.

109 Innovative Design Protection Act of 2012, S. 3523, paras 2(a, f) (112th Cong., 2d Sess.).

110 See, e.g., 2008 Hearing, supra note 95 at 32-33 (Statement of Steve Maiman).
} 
consumers. ${ }^{111}$ In a separate statement to the Senate Report accompanying the bill, these Senators noted the "lively debate" over the economics of design protection, and cautioned that "absent a stronger showing that a practice is systematic and harmful to the market as a whole, the threat of encroachment on liberty represented by any congressional enactment tips the balance against government intervention in the private market."112

1. Politics, power, and pendulum swings.

The lack of compelling economic support for fashion rights provides a plausible, but incomplete, picture of why the legislation has repeatedly stalled in Congress. In the recent past, Congress has often pointed to global norms as justification for expanding intellectual property rights, ${ }^{113}$ so one might expect it to follow Europe's lead in creating a sui generis regime. And if Congress conditioned new intellectual property rights on a demonstrated need for incentives, the US intellectual property landscape would look quite different than it does today. ${ }^{114}$ Equivocal economic evidence alone, then, can't explain the impasse on design. The rest of the story likely owes itself to some combination of politics and timing.

First, unlike many of the more established "IP industries," the fashion industry has neither the economic footprint nor the political clout to command much attention in Washington. ${ }^{115}$ Thus, while some sponsors like New York Senator Chuck Schumer have a sizable constituency that cares about design rights, the design industry plays a fairly minor role in the national economy and political debate, at least relative to the collective "content industries" that include music, movie, software, and book publishers. The existence of major discount retailers with interests on the other side, moreover, only further weakens the political force behind the drive for fashion protection.

Second, this latest round of fashion legislation comes at a time of (relative) skepticism about overly broad intellectual property rights. Congress has, in recent years, worried over patent trolls and trademark bullies, and scholars have demonstrated that intellectual property rights can impose substantial costs and hamper innovation

\footnotetext{
111 S. Rep. No. 112-259 at 10 [2012].

112 Id.; see also 2011 Hearing, supra note 95 at 10 (Statement of Rep. Melvin L. Watt) (recognizing the "gap" in intellectual property law that allows fashion "knock-offs," but warning that gaps alone do not justify new intellectual property rights: "The question is whether this gap is detrimental to intellectual property rights or whether the existing framework provides all of the protection that is necessary to meet the Constitutional goal to stimulate and promote innovation within the fashion industry.").

113 E.g., H. Rep. No. 105-452 at 4 [1998] ("In 1995, the European Union extended the copyright term for all of its member states from life of the author plus fifty years to life of the author plus seventy years. As the world leader in the export of intellectual property, this has profound effects for the United States if it does not extend copyright term as well.").

114 See supra note 6.

115 See K. Abnett, 'Money Well Spent? Why Fashion Companies Spend Big on Lobbying Governments' (Business of Fashion 27 October 2015) <https://www.businessoffashion.com/articles/intelligence/moneywell-spent-why-fashion-companies-spend-big-on-lobbying-governments> accessed 24 November 2017 (noting some of the reasons for the fashion industry's lack of success in lobbying for design legislation).
} 
rather than inspiring it. ${ }^{116}$ It is not surprising, then, that the legislative history of the fashion bills reflects sensitivity to the costs of unnecessary new rights. ${ }^{117}$

Finally, the long history of failed attempts at sui generis design protection no doubt played an unstated role in the latest bills' failure. Fashion designers have complained about copying for well over a century, and Congress has repeatedly come close to relenting, but ultimately resisted. Although new technology has sped the pace of copying, it has not produced any fundamental change in the economic structure of the fashion industry. Absent some evidence that new conditions raise a heightened risk of market failure, Congress appears to be staying the course.

\section{Conclusion}

Given the fraught history of design legislation in the US, the new popularity of design patent law, and the different philosophical foundations of intellectual property law in Europe and the United States, the US may never adopt the "design approach" and create a Community Design System-like regime. Indeed, unless the popularity of design patents begins to reverse itself, there may be little push for such a system for anything other than fashion.

Yet history suggests that the fashion industry, at least, will someday renew its appeal for industry-specific protection. To some extent, the success of that appeal will depend on factors such as the political climate and the legislature's overall level of function (or dysfunction). But it will also turn on evidence - evidence that fashion design protection will not only benefit designers, but will improve overall welfare in the US fashion market. Empirical studies of the price and quality effects of the Community Design System, for example, could inform the conversation; so could data on licensing practices in the US compared to Europe. Such evidence might make the case that design protection fits into the utilitarian architecture of US intellectual property law; without it, the status quo will likely prevail.

\footnotetext{
116 See, e.g., J. Bessen and M. J. Meurer, 'A Third of the Economy Is At Stake - and Patent Trolls Are to Blame’ (Wash. Post 18 November 2015), <https://www.washingtonpost.com/news/intheory/wp/2015/11/18/patent-trolls-are-costing-us-billions-they-must-bestopped/?utm_term=.e08dd01243c7> accessed 24 November 2017.

117 See S. Rep. No. 112-259 at 9 [2012] (Minority Views on 2012 bill) ("We have learned from experience that legislation has many consequences, some of which can be unintended, unforeseen, and negative. That same experience reveals a legislative propensity towards expanding rights once created. By contrast, Congress has been much less successful paring down statutory rights, even where evidence demonstrates that such rights have become overly-broad.”).
} 